\title{
Travel, leisure, boredom and the Middle Ages
}

\author{
Maja Jović
}

\author{
Review article \\ UDK 316:338.48>"653"
}

\begin{abstract}
The subject of this analysis deals with the concepts of travel, leisure and boredom, with emphasis on the medieval period. What was travel to a man of the Middle Ages, and was there any place in his life for leisure, and especially boredom? Either in opposition to each other or one inside the other, homo faber, homo viator and homo ludens coexist. Entering the medieval imaginarium, we inevitably enter a sphere of three layers of societal stratification (oratores, laboratores, bellatores). The subject of this study is to consider all three layers such that we view them as structures within a system, called Christian humanism: a system of collective identity shaped through ecclesiastical ideology that indoctrinates its own structures.
\end{abstract}

Keywords: Middle Ages, travel, leisure, boredom, system

\section{Introduction}

As is evident from the title of this study, the subject of its analysis, or reflections, refers to concepts of travel, leisure and boredom, with emphasis on the medieval period. What was travel to a man of the Middle Ages, and was there any place in his life for leisure, and especially boredom? This opens questions pertaining to microhistory, or historical anthropology, on the one hand, and philosophical considerations that assume encroachment into the metaphysical on the other. Either in opposition to each other or one inside the other, homo faber, homo viator and homo ludens coexist. The terms work, travel and play are well known to the contemporary man. We know what we do when we are at work, how, when and where we travel, and finally, who plays and how. However, 
does the same apply to the medieval period? Without giving it too much thought, we would say that it is not. The time gap, as the basic obstacle to the possibility of deciphering the motivation underlying the actions of people from past times, shapes our thinking.

People have a common denominator which encompasses the concept of existence and, inevitably tied to that, perception of the question of meaning. The struggle and the questions are the same, only differently conditioned by time and space. The categories of time and space function differently within a specific period. Perceptions change. Their conditionality generates other conditionalities, such as work, leisure, travel and boredom in this case.

Entering the medieval imaginarium, we inevitably enter a sphere of three layers of societal stratification. Thus, according Duby's distribution, we observe those who pray, those who work, and those who fight (oratores, laboratores, bellatores). The subject of this study is to consider all three layers such that we view them as structures within a system, called Christian humanism. The system of collective identity is shaped through ecclesiastical ideology that indoctrinates its own structures. Such considerations may be regarded as fairly general. However, if we adhere to the fact that faith was one of the most vital elements of society at the time, it is possible to justify the aforementioned.

We will analyse the functioning of time and space categories in the following three chapters, firstly relating to travel, then to leisure (and thus work), and finally to the philosophical concept of boredom. Horror vacui and horror loci, which are intertwined, will serve as basic guidelines, i.e. operative terms to justify the above-mentioned denominator.

\section{Travel}

According to the science of Iterology, travel is human relocation. Therefore, attention is accorded to human migration, barbarian invasions, military campaigns - in other words, whenever people cross from one territory to another. The political macrohistory that has defined the map of the world over time will not be discussed here.

Le Goff warned us that it is impossible to understand any society unless we investigate the functioning of time and space categories, because we will not understand history if we do not see it as a combination of structures of material and symbolic realities. The space of the Middle Ages is a space designed as a realization of collective identity (Le Goff 1998). Ohler's study The Medieval 
Traveller and Foster's Pilgrims are both very good and detailed manuals if one is curious about who travelled and how, where they were headed to and why, their motivation and conditions, and descriptions of travel in the Middle Ages. To know the motivation for travel, we need to know the context, i.e., the image of the world in the Middle Ages.

The macabre vision, or memento mori, ars moriendi, which emerged from theological foundations, also determines the idea of a geographical horizon that, according to Bloch, in turn also becomes a spiritual horizon. It also underscores an enormous indifference to time, a certain pessimism, a lament over the present, and of inspiration for cartography which is inspired by the theological concept (Le Goff 1998; Huizinga 1991).

"Medieval man firmly believed that everything in the universe had a supernatural significance, and that the world is like a book written by the finger of God. Every animal had a moral or mystical significance, as did every stone and every plant (and this is recounted in the bestiaries, lapidaries and herbaria)" (Eco 2004: 121).

Nevertheless, people from the Middle Ages were mobile, and motivations for travel varied. Those who prayed travelled differently than those who travelled for work or who fought in wars. The conquest of space implies military campaigns with the purpose of territorial appropriation and occupation of land with the aim of exhausting its resources. Everyone moves for a reason. Medieval knights were a group characterized by spontaneous curiosity and a kind of exoticism, which complied with a vocation that required adventure and discovery of new locations. Duby concluded that even the Crusades were nothing more than an excuse for extraordinary travels (Duby 2006). The farther away from home and everyday life, the better and more interesting the destinations were (Foster 1986). Farmers, who constituted the majority of society at the time, would leave their land that no longer yielded crops and places where the climate had become ruthless to settle in new, supposedly good places for a new, better life. Hunger, disease, greed and death "mounted their steeds" and changed borders. An apocalyptic mood served to create a new map for a new Europe. We find the obsession for food and persecution by hunger present among both rich and poor, in the hagiographic writings and legendary royal genealogies. The Great Famine of 1125 "left" its mark in ministerial records that mention "devouring", in heroic epics where giants (Pantagruel's ancestors, ogre brothers) have an incredible appetite, as well as in an exceptional document (The History of Reynard the Fox 
- Le Roman de Renart) in which the parodied animals on a banquet represent the nobility (Le Goff 2009).

The third figure in this division was the one who prays, preaches and spreads spiritual and mental horizons. Pilgrims saw the meaning of their travel in penance, the desire for forgiveness, and conversion to Christianity. However, seeing relics of a beloved saint, or visiting popular pilgrimage sites such as Rome, Jerusalem and Santiago de Compostela, also sufficiently evoked the exotic, the mystical and the motivational to risk travel, even though this entailed peril at that time. Figuratively speaking, Europe was a big forest, a world of darkness, filled with wild animals, especially wolves, and measurement of time came down to the ringing of church bells, if and only if the traveller happened to be near an inhabited area. Considering the above, the traveller was not a passive observer. On the contrary, by constant anxiety about success of the undertaken difficult journey, the traveller would only confirm his/her status of an active participant. It is necessary to mention yet another aspect of pilgrimage, popular entertainment, which was an integral part of this culture. Pilgrimage sites, fairs or inns were way-stations where lovers met, places to gather and trade pious souvenirs, places bustling with jugglers, dancers, singers, pickpockets, sword swallowers...It may be concluded that pilgrims represented the political and cultural driving force for the entire Carolingian Empire and facilitated its momentum (Foster 1986).

Besides these social groups, it is impossible not to mention those living on society's margins, such as wanderers, jesters, jugglers, prostitutes, pirates, smugglers, flagellants, beggars, the ailing, criminals and goliards, who also travelled, continually changing their place of residence in search of a "meaningful" life.

So we come to this question: is the conquest of space also the conquest of time? If space is conquered, is time also conquered and thus, in a sense, embodied? Is travel a response to existential anxiety, a desire for cognition/knowledge? Metamorphosis of space into a place, whereby an essential prerequisite in creating a sense of place imposes the concept of time, indicates that "space is a practical place", and emphasizes change and process. These are locations in which people create long-term memories, which are never completed and are always emerging (Certau 2003/1990/). Change of space conditions a different context, and that in itself is also an ontological change in a person. Movement is a sort of process, a path that needs to be crossed to achieve meaning. 
$64 \mid$

"Though in itself inseparable from any Christian representation of the universe, the image of the final catastrophe had seldom impinged so strongly on the consciousness of men as at this time. They meditated on it; they assessed its premonitory signs.... But is the period of waiting made less anxious by ignorance of when the blow will fall? ... If humanity as a whole seemed to be moving rapidly towards its end, so much the more did this sensation of being 'on the way' apply to each individual life. According to the metaphor dear to so many religious writers, the true believer was in his earthly existence like a pilgrim, to whom the end of the road is naturally of more importance that the hazards of the journey" (Bloch 2001: 92-94).

"To follow Christ or to rule the World" (Duby 2006: 301) - this is an aspect of ambivalence that permeates a man on his journey, and is a reflection of his decisions as such. If we were to think of paths, actual, physically travelled paths, as a metaphor for the abstract journey of life, then we engage in the interpretation of human life through stages: from birth to death, from ignorance to insight. On the basis of such a formulation, we find the Bildungsroman as an example, and just for the sake of comparison, Voltaire's Candide also travels down paths and finds himself on journeys of life.

Merchants, messengers, scouts, as typical examples of fast walkers, have covered 25 to 60 kilometres daily, depending on the type of terrain. And the only real adventurers, in the eyes of medieval Christians, were the ones who surpassed the boundaries of Christianity: missionaries or merchants who disembarked in Africa, the Crimea or entered deeper into Asia (Le Goff 2009). The emphasis was on the term "surpass the boundaries of Christianity"; the entire spectrum of attitudes toward travel can be clearly discerned from such a notion. And the very act of going from the known to the unknown is an act of research. The image of the ship in a storm is slightly clichéd, as is the miraculous salvation by a saint. If we translate this sentence into an abstraction, and if we remember the story of Virgil and the ship, we would say that man is on the "storm-tossed sea" of life, and God is the truth, the truth that liberates. And thus will the famous scholastic "Gaelic Aristotle", Abélard, say: "upon departure: we suspect ... but during the search we reach the truth" (Duby 2006: 161).

In his Historia Calamitatum (The Story of My Misfortunes) and Letters to Heloise, Abélard talks about his viewpoints, criticizing society and the times, claiming: "As if he was destined not to settle anywhere until he had experienced everything, both physically and mentally, and from those very conflicts show 
everyone that he would rather endure his troubles than capitulate in a world full of deception and sin, which was protected by all of that time's symbols of holiness" (Bošnjak 1992: 232).

Furthermore he says, "that which is not experienced is impossible to know" (Bošnjak 1992: 239), and that directs us to an active traveller who fills his catalogue of experiences during his travels, from which he will draw material for later knowledge.

We can say without reservation that pilgrimage was a medieval form of tourism, ${ }^{1}$ a pretext for wandering and aimless curiosity (Le Goff 2009). From the modern standpoint, we know that not everyone can travel, so to speak. A very dangerous manifestation of vanity for the time, it was justified by citing Christ's instruction to all people: "Leave everything and follow me". We should not prejudge and claim that people always had salvation on their mind; there were certainly those who failed to articulate that salvation consciously, but simply had within them an urge for something different.

“... Montaigne says, adding that to those who ask him why he travels, he usually gives two arguments: first, that he is fully aware of what he is running from, but does not know what he is looking for, and second, that we always benefit when we replace a bad state with a state of uncertainty" (Duda 2012: 151).

Perhaps the idea of synthesizing homo viator, homo faber and homo ludens into one matrix is far-fetched. However, solely by thinking about homo viator as a curious sensation seeker, we come closer to homo ludens, and when we say former travels, while the latter plays, we conclude that both are doing something. And here we come to the third category, homo faber.

1 In his study Rojek claimed that tourism and culture overlap and that there is no clear boundary between the two (Rojek 1997). 


\section{Leisure}

The concept of leisure ${ }^{2}$ inevitably evokes the concept of work, which in the medieval social hierarchy directs us to laboratores, and, in the context of this analysis, to the operative term of homo faber. "Kant claims that humans are the only animals with an existential need for work" (Svendsen 2012: 41), but also for leisure, as Aristotle added. Furthermore, he claimed that leisure is the foundation of everything, and that it needs to be "ranked higher than work, because leisure is the latter's target" (Huizinga 1970: 214).

"Bowmen bend their bows when they wish to shoot; unbrace them when the shooting is over. Were they kept always strung they would break, and fail the archer in time of need. So it is with men. If they give themselves constantly to serious work, and never indulge awhile in pastime or sport, they lose their senses, and become made or moody. Knowing this, I divide my life between pastime and business" (Herodotus, Histories, Book II, cited in Svendsen 2012: 85).

To divide one's life "between pastime and business" undoubtedly implies time for work and time for rest in this context. Let us go back to Duby's division and compare the three social classes from the perspective of the meaning of work. Those who pray, referring to the clergy in the narrow sense, have their task in their services mainly in the monastic environment. Just remember Benedict of Nursia, the founder of the Benedictine Order, whose rule was: ora et laborapray and work. Knights also did their duty (work) for their kingdom, as did the peasantry, whose work was meticulously ordered and organized by the feudal system. Abstracted, the functions of their work were subordinated to and motivated by the organic status of each individual. What we want to emphasize is the concept of need, which Kant attempted to grasp, claiming that existential need "is not one for work as such, but rather for meaning. ... The need for meaning is a fundamental human need, and work is one of the primary sources of such meaning" (Svendesen 2012: 42).

${ }^{2}$ We will highlight a few basic guidelines: "It is the antithesis of the economic function of labor which carries along a pleasant anticipation and memory, includes a minimum of unwanted obligations related to the social role, is associated with freedom and choice, is closely related to the values of culture, involves an element of play and series of activities that 'stretch' from unconscious activities to activities of importance" (Rojek 2010). 
If work is set as an indicator in search and validation of meaning, then the concept of leisure by its "definition" is largely equated with the concept of work. In fact, something may be work for one individual, but this same thing may be for someone else. We cannot ignore the fact that the individual forms his/her social identity not only through work, but also through the manner of leisure. Leisure is defined as free time, but "free from what?" (Wynne 1998: 28-29).

Above all, I would like to emphasize that this is only one of the perspectives for understanding the relationship between work and leisure, whereby, in a way, the inability to separate work from leisure is expressed. If we look at everyday life - which is, granted, perhaps over-generalized - it is noticeable that both our working hours and our leisure time are structured.

"The temporality of work has invaded our leisure, making it a lot like work, and 'real work' can often appear to be a relief compared to the 'pseudo-work' of our leisure" (Svendsen 2012: 91).

The question is: did the medieval pilgrim work, travel or rest? Maybe it is this medieval figure that is the synthesis of all three functions.

\section{Boredom}

Social construction of the concept of boredom is found in the $18^{\text {th }}$ century, but what was the equivalent to that concept in previous periods? The Latin word acedia is a possible synonym, and it is a concept that has moral connotations, and this marked the specific mood akin to boredom in the Middle Ages. Negatively connoted, and certainly sinful, it represents a form of the disease, i.e. a medical problem (use of the term melancholy is typical of the Renaissance) in the $14^{\text {th }}$ century (Svendsen 2010: 63). It was a negative phenomenon that evoked questions of meaning and existence, denoted a lack of events, and was the source of all evil as such. Those who succumbed to acedia, so-called acidos, as it is called by Dante in Canto VII of his Divine Comedy, ended up in a deep quagmire from which they gurgle songs about their punishment for the foul mood to which they succumbed, instead of rejoicing in the sun (Svendsen 2010: 62).

When we talk about boredom, we imply the flow of time, a category of duration that needs to be filled with some kind of meaning. The most prominent in this concept are horror vacui and horror loci. Time passes slowly, or does not pass at all, in boredom. Space is filled with a vacuum. In this sense, the void is the exact equivalent to boredom, a warning that intimates slow death, a true memento mori. Awareness of dying, which assumes an even more frightful 
dimension if we have not lived meaningfully and filled the category of fluency, will be realized in an anxious stimulus prompted by any exile. Moving, which takes time, also entails a change of space. But the question is how to see meaning in such action.

Pascal warned that boredom has no particularly important social dimension, but should be understood as a feature of every man. "Without God man is nothing, and boredom is the awareness of that nothing" (Svendsen 2010: 65). This formulation is very well suited for the medieval man. Namely, in the imaginary of the state of God, all follow Him and, by analogy, seek and confirm meaning and reveal the essential truth of their own life. The phrase pilgrims of the world corresponds to the Middle Ages more than any other period. Fear of boredom, or even spleen, challenges homo faber, encourages him to act, and in this sense each of the classes will try to achieve victory in their own way. Kant argued that: "Without work, we would simply be bored to death because work provides our life with content. He argues that amusements cannot fill this function in the long run and that a person who fills his or her life only with amusements will feel increasingly 'lifeless'” (Svendsen 2012: 41).

"Work therefore is desirable, first and foremost, as a prevention of boredom, because the boredom that a man feels when he is doing necessary but uninteresting work is nothing in comparison with the boredom that he feels when he has nothing to do with his days" (according to Russel 1930/1996/, Svendsen 2012: 88).

Fear of empty space is evident in medieval architecture, especially in the example of gothic cathedrals. Ribbed vaults, rosettes, sculptures, stained glass, illuminated texts and other decorative elements, are all examples of the objectification of space. Expressiveness of expression based on the impression of experience of nature, man's inwardness, and experience of the world in general point to the need of medieval men for the articulation of their own life. Symbolism and allegory were in full swing in the Middle Ages, thus church buildings were built with tall windows that suggest to the sublime, i.e. nearness to God.

Churches were the tallest buildings at that time; everything was measured according to them and they were the measure off all things. Hence, from place to place residents competed as to whose bell tower was higher, who was closer to the Almighty, to conquer space, and thus time. A properly built and decorated cathedral was prevented the absence of amor vacui toward God. 
If we attempt to reconcile work and play into one, homo faber will assume the contours of homo ludens. The definition of play "is a voluntary activity or occupation executed within certain fixed limits of time and place, according to rules freely accepted but absolutely binding, having its aim in itself and accompanied by a feeling of tension, joy and the consciousness that it is 'different' from 'ordinary life'. ... We ventured to call the category 'play' one of the most fundamental in life" (Huizinga 1970: 44).

Huizinga claimed that culture in its form arose from play, and that culture is already played from the beginning (Huizinga 1970: 67). Identity and culture are mutually contingent, and one anticipates the other. In its own fashion, religion, which functions as a cohesive bond inside social structures, excludes distinctions, and in this sense the medieval imaginary functioned as a single entity. Theological thought directed its subjects in the medieval world were on how they were to play and create culture. A well-established hierarchy dictated the formation of structures within the system, and thus determined the division of roles in the creation of collective identity.

Culture and play are intertwined in the process of creation that springs from anxiety, and they reflexively shape an activity that will result in the ontological transformation of man. According to Plato, the sameness of play and ritual act goes without question (Huizinga 1970: 29-31). Play is an act, activity, that is an organically integrated component of the function of confirming existence itself. Additionally competition and victory are vital components of play.

"What is 'winning', and what is 'won'? Winning means showing oneself superior in the outcome of a game. ... [The winner] has won esteem, obtained honour; and this honour and esteem at once accrue to the benefit of the group to which the victor belongs. ... The primary thing is the desire to excel others, to be the first and to be honoured for that" (Huizinga 1970: 73).

The competitive spirit, as a biological and social function, is a feature that also manifests at the creative level, the competence of an individual in the 'design' of everyday life. It can be said that every human act is a function of play, and that the degree of culture is determined according to the level of playfulness. The cultural field is a competitive arena, a training ground for the affirmation of life and art of living. 
The Middle Ages had its homo ludens, and his cultural field was the horizon of Christianity. It is almost impossible to exclude the context of conditionality of the boundaries between time and space in that period. As a result of humanity's accomplishments, meaning the discovery of other worlds, the man of that time, prompted by the symbolism of the Apocalypse, achieved and designed his times just as opportunities allowed. Regardless of different conditioning, homo ludens of the Middle Ages became homo faber and homo viator as well, forming his own unique culture on the diachronic scale of human civilization.

\section{Conclusion}

The final synthesis of thoughts arising from the previously interpreted themes forms a dialectical system whose components are the concepts of amusement, boredom, work, leisure, rest and travel. Correlation within the system generates a set of laws governing play, and culture for that matter. Variability within the field of one component will result in changes to the overall system. The aim of this study was to examine the functioning of these structures within a given historical period, in this case the Middle Ages. Knowledge derived from the Middle Ages leads to the conclusion that this period can be viewed as a model for a system in which social structures are quite clearly defined, provided, naturally, that we adhere to the triple division. It is necessary to note that awareness of marginal groups, which were necessarily excluded to the 'margins of society' (and merit more detailed research), did not get lost during interpretation. Judging by the aforementioned, the inevitable question that arises is whether we can discuss a historical period in general as some sort of system. How is it possible to argue about the laws of behaviour if there is a possibility of deviation, which thus gives us the impression of chaos? By this I mean the equation which is obvious in the theory which places human life under a common denominator, and which directly implies a sort of unity in opposition to generally accepted universals.

This theory posits that homo faber, homo viator and homo ludens serve the function of proving the denominator which conceals existence, and hence meaning. Time and space imply interferences are inevitable, and as such imply possible chaos in the system. Anomalies generated by chaos are normally immeasurable and unknown. However, if we consider these so-called irregularities as unique moments typical of each individual in the context of play or the creation of culture, we will designate them as creative moments. We have 
already mentioned how culture and identity function on the basis of mutual selfaffirmation. The medieval imaginary, as a system, produces two fields of culture: high (superior) and low (folk, inferior). In any social field, culture is a different manifestation of identity affirmation. For example, it is a generally-held principle that the literate layer of society produces "high" culture, while the illiterate, common layer, achieves its height in oral literature, carnivals and folklore. If we set forth from the fact that play is the universal means of generating culture, in accordance with the above-mentioned social division, we may also assume a form of playfulness, or cultural production. Generally, the contestable aspect in this entire theory is the possibility of induction of the validity of social behaviour patterns, as well as the validation of possible irregularities. Let us say that because a pattern of behaviour is conditioned by religiosity, as well as the transience and reminder of mortality so typical of this period, each of these cultures will generate ars moriedi models in their own way. Creative moments as the criteria for measuring playfulness point to the selection of a path, manner of work or 'quantity' of boredom. The selection will determine the culture.

The tendency toward the creation of this type of mental construct is driven by reflections about the relationship between microhistory and macrohistory, as systems within a system, mutual relativity, chaotic moments in both and, of course, regularity, which are canonically systematized and thereby mould each of the systems. Social construction of each of these concepts indicates ambiguity, and thus possible approaches to interpretation. I hope that this study has confirmed that ambiguity once again.

\section{Bibliography}

\section{BLOCH 2001}

March Bloch, Feudalno društvo, tr. M. Brandt, Zagreb 2001.

\section{BOŠNJAK 1992}

Branko Bošnjak, "Petar Abelard - srednjovjekovni racionalist," in: Peter Abelard, Povijest nevolja Etika. Pisma Abelarda i Heloize (tr. V. Gortan and V. Vinja), Zagreb 1992, 231-250.

CERTAU 2003/1990

Michel de Certau, Invencija svakodnevice, tr. G. Popović, Zagreb 2003/1990.

\section{ČAPO AND GULIN ZRNIĆ 2011}

Jasna Čapo and Valentina Gulin Zrnić, Mjesto, nemjesto.

Interdisciplinarna promišljanja prostora i kulture, Zagreb 2011. 
72 |

DUBY 2006

Georges Duby, Vrijeme katedrala. Umjetnost i društvo 980. - 1420 (tr. E. Agotić), Zagreb 2006.

DUBY 2007

Georges Duby, Tri reda ili imaginarij feudalizma (tr. O. Škarić and N. Desnica-Žerjavić), Zagreb 2007.

DUDA 2012

Dean Duda, Kultura putovanja, Zagreb 2012.

ECO 2004

Umberto Eco, Povijest ljepote (tr. V. Mikšić), Zagreb 2004.

FOSTER 1986

Norman Foster, Hodočasnici (tr. M. Popović), Zagreb 1986.

GUREVIČ 1981

Aron Gurevič , Problemi narodne kulture u srednjem veku, tr. L. Subotin, Beograd 1981.

HUIZINGA 1970

Johan Huizinga , Homo ludens. O podrijetlu kulture u igri (tr. A. Stamać), Zagreb 1970.

HUIZINGA 1991

Johan Huizinga, Jesen srednjega vijeka (tr. D. Perković), Zagreb 1991.

LE GOFF 1998

Jacques Le Goff, Civilizacija srednjovjekovnog zapada (tr. G. V. Popović), Zagreb 1998.

LE GOFF 2009

Jacques Le Goff, Intelektualci u srednjem vijeku (tr. M. Vekarić), Zagreb 2009.

OHLER 1989/1986

Norbert Ohler, The medieval traveller, Woodbridge 1989/1986.

ROJEK 1997

Chris Rojek, Touring cultures. Transformations of travel and theory, London 1997.

ROJEK 2010

Chris Rojek, The labour of leisure. The culture of free time, London 2010.

SVENDSEN 2010

Lars Fredrik Svendsen, Filozofija dosade (tr. Z. Petir), Zagreb 2010.

SVENDSEN 2012

Lars Fredrik Svendsen, Filozofija rada (tr. M. Herman and M. Herman), Zagreb 2012.

WAYNE 1998

Derek Wayne, Leisure, lifestyle and the new middle class, London 1998. 